\title{
Pengaruh Culture Event di Anjungan Bengkulu Taman Mini Indonesia Indah Jakarta Terhadap Citra Destinasi Wisata Provinsi Bengkulu
}

\author{
Annisa Asri Lestari, Bagja Waluya dan Rini Andari \\ Universitas Pendidikan Indonesia \\ riniandari@upi.edu
}

\begin{abstract}
Bengkulu is one of the provinces in Indonesia, which has many potentials in terms of natural and cultural diversity. Looking at the numbers of potentials for cultural tourism around the province, Bengkulu Province was expected to increase the number of tourists for its unique characteristic and good image adhering in the minds of prospective tourists as a cultural destination. Problems occurred in Bengkulu Province is a fluctuating level of tourist visits to the province, and the growth level tends to be low. This is due to the image of Bengkulu Province as a tourist destination that is not good enough in the minds of prospective tourists. Hence, Anjungan Bengkulu, which is located in Indonesian Miniature Park, Jakarta was having the effort to overcome this problem. Therefore, the researcher chose Cultural Event as the solution that can be implemented to improve the Destination Image of the province. On this study, the independent variable (X) was Cultural Event, consisting of Spectacularisation, Theme, Participation and Immersion. The dependent variable (Y) was Destination Image. The type of the research used was a descriptive explanatory survey, and supported by the cross-sectional method. The samples in this study were 108 respondents consisting of individual visitors at the Anjungan Bengkulu Cultural Event, the sampling technique used was purposive sampling. Data analysis technique employed was multiple regressions. The result showed that the implementation of Cultural Event at Anjungan Bengkulu was assessed in the high category, with a dimension of "Spectacularisation" received highest score, and the lowest one was the "theme". Subsequently, visitors' response regarding Destination Image at Anjungan Bengkulu was also categorized in a very high level, with a dimension of cognitive image received highest score and dimension of affective image became the lowest one. Results showed that there is a significant influence between Culture Event and Destination Image.
\end{abstract}

Keywords-cultural event; destination image.

\section{Pendahuluan}

Seiring berkembangnya pariwisata di Indonesia, daerah-daerah di Indonesia mengupayakan berbagai cara untuk menunjukkan diferensiasi dibandingkan dengan kota-kota lainnya sesuai dengan UndangUndang No. 32 Tahun 2004 tentang otonomi daerah. Undang-undang ini menyebutkan bahwa dengan adanya potensi, keanekaragaman daerah, peluang dan persaingan global maka dari itu diberikanlah wewenang yang seluasluasnya kepada daerah, serta pemberian hak dan kewajiban menyelenggarakan otonomi daerah. Melalui undang-undang tersebut banyak pemerintah daerah mulai menawarkan potensi daerahnya masing-masing sebagai upaya meningkat Pendapatan Asli Daerah (PAD). Salah satunya adalah Pemerintah Daerah Provinsi Bengkulu.

Provinsi Bengkulu merupakan salah satu provinsi yang memiliki keanekaragaman potensi alam dan budaya. Provinsi Bengkulu terletak di sumatera bagian selatan, berbatasan dengan Sumatera Barat, Lampung, Sumatera Selatan, Jambi dan Samudera Hindia dengan luas wilayah sebesar $19.788,70 \mathrm{~km} 2$. Provinsi Bengkulu kaya akan potensi wisata alam, budaya dan sejarah. Terdapat 189 destinasi wisata di Bengkulu yang terbagi ke dalam golongan destinasi wisata alam sebanyak 169 dan heritage (budaya/sejarah) sebanyak 20, yang tersebar di 9 kabupaten dan 1 kota.

Melihat banyaknya potensi pariwisata dan budaya di Provinsi Bengkulu tersebut diharapkan berbanding lurus dengan jumlah kunjungan wisatawan ke Provinsi Bengkulu. Namun, jumlah wisatawan yang berkunjung ke Provinsi Bengkulu 5 tahun terakhir dilihat dari jumlah tamu menginap di hotel berbintang/nonbintang pada tahun 2016 fluktuatif dan pertumbuhannya hanya sedikit. Dilihat dari kompetitornya, Provinsi Bengkulu berada pada 
peringkat terakhir jumlah kunjungan pariwisata pada tahun 2016. Menurut Ali Paseh selaku Kepala Seksi Promosi dan Informasi Provinsi Bengkulu kompetitor dipilih karena wilayahnya yang berdekatan dengan Provinsi Bengkulu, yaitu Lampung, Jambi, Sumatera Selatan dan Sumatera Barat. Selain wilayah berdekatan, Provinsi Bengkulu telah mengalami akulturasi budaya dengan keempat provinsi sekitar, sehingga lima provinsi tersebut memiliki karakteristik yang hampir mirip namun terdapat ciri khas yang berbeda di tiap provinsinya.

Ada beberapa faktor penyebab pertumbuhan wisatawan yang fluktuatif dan menyebabkan Provinsi Bengkulu memiliki peringkat paling akhir, salah satunya adalah kurang melekatnya citra pariwisata Provinsi Bengkulu di benak wisatawan. Salah satu Citra yang kini sedang dibangun Pemerintah Provinsi Bengkulu adalah wisata pegunungan kawasan konservasi bunga rafflesia di hutan lindung Kabupaten Kepahiang. Bunga rafflesia merupakan flora endemik Provinsi Bengkulu. Habitatnya berada di kawasan hutan lindung $1000 \mathrm{~m}$ diatas permukaan laut di Kabupaten Kepahiang dengan ekosistem yang masih asri. Oleh sebab itu di dalam Rencana Induk Pengembangan Pariwisata Daerah (RIPPDA) pengembangan wisata alam pegunungan kawasan konservasi bunga rafflesia khususnya di kawasan hutan lindung Kabupaten Kepahiang sedang diutamakan untuk dikembangkan dan dipromosikan (sumber: bkpmdbengkuluprov.go.id). Sedangkan review pada Trip Advisor menyatakan bahwa sebanyak $50 \%$ netizen merekomendasikan destinasi wisata pantai dan tidak ditemukan review mengenai destinasi wisata alam pegunungan yaitu kawasan konservasi bunga rafflesia di hutan lindung Kabupaten Kepahiang.

Adapun komentar dari hasil review tersebut sebagian besar netizen mengeluhkan akses jalan yang kurang baik, hal ini didukung dengan pemberitaan di liputan6.com bahwa kurang terawatnya akses jalan di Provinsi Bengkulu sehingga mengurangi rasa keyakinan memilih pada calon wisatawan, selain itu banyak juga review yang menyebutkan masyarakat Provinsi Bengkulu masih kurang sadar akan pariwisata sehingga penduduk dinilai kurang ramah kepada wisatawan dan tingkat kriminalitas masih cukup tinggi. Provinsi Bengkulu terus berupaya melakukan perbaikan jalan. Tahun 2016 telah dibangun $1200 \mathrm{~km}$ jalan seperti yang dilansir pada mediaindonesia.com. Selain memperbaiki akses jalan, Dinas Pariwisata Provinsi Bengkulu mengadakan pembinaan kelompok sadar wisata kepada 50 perwakilan dari tiap kabupaten/kota demi terwujudnya masyarakat sadar wisata yang mendukung program Visit Bengkulu 2020 (sumber: harianrakyatbengkulu.com).

Setelah melakukan perbaikan infrastruktur, Pemerintah Provinsi Bengkulu juga melakukan upaya promosi untuk memperbaiki citra Provinsi Bengkulu. Salah satunya melalui eventevent pariwisata yang diadakan di Provinsi Bengkulu dan di luar, baik pada taraf nasional maupun internasional. Salah satu event internasional yang diikuti di luar Provinsi Bengkulu adalah Malayasian Association of Tour and Travel Agents (MATTA) Fair 2017 yang diadakan pada 17-19 Maret 2017 di Putra World Trade Center (PWTC) Kuala Lumpur (sumber: harianrakyatbengkulu.com).

Sejalan dengan event yang telah diikuti di luar negeri, Provinsi Bengkulu juga sering mengadakan dan turut berpartisipasi dalam event yang terdapat di dalam negeri dan di luar Provinsi Bengkulu, yaitu melalui kantor penghubung di Jakarta pada sub bidang Seksi Promosi dan Informasi Anjungan Bengkulu Taman Mini Indonesia Indah yang merupakan Unit Pelaksana Teknis Daerah (UPTD) Dinas Kebudayaan dan Pariwisata Provinsi Bengkulu. Anjungan Bengkulu TMII adalah miniatur dari Provinsi Bengkulu yang merupakan cerminan dari keseluruhan Provinsi Bengkulu.

Sesuai dengan visi dari Seksi Promosi dan Informasi Anjungan Bengkulu yaitu menjadikan anjungan daerah sebagai show window daerah yang di dalam misinya terdapat upaya meningkatkan promosi potensi unggulan daerah salah satunya pada bidang pariwisata dan budaya, Seksi Promosi dan Informasi Anjungan Bengkulu melakukan berbagai macam culture event promosi baik di dalam maupun di luar kawasan Anjungan Bengkulu untuk meningkatkan citra destinasi wisata Provinsi Bengkulu.

\section{KAJIAN PUSTAKA}

\section{A. Culture Event}

Shone dan Parry di dalam Any Noor (2013:9) mengungkapkan bahwa culture event berada di dalam special event, yang terdapat di dalam publicity and public relation dan dinaungi oleh marketing communication mix. Culture Event merupakan suatu aktivitas budaya, yang sebelumnya disajikan dalam pola yang teratur, terus menerus, dan akan dikonfigurasikan ulang tepat untuk membuat event yang baru. Jennie (2015:1).

Terdapat beberapa dimensi dari culture event yang diadopsi melalui event yang dicapai beberapa penelitian terdahulu. dimensi yang digunakan dalam penelitian ini terdiri dari 
Spectacularisation, Theme dan Immersion and participation menurut Jennie (2015:9), yaitu:

\section{a. Spectacularisation}

sesuatu yang sangat visual dan lebih besar, serta memiliki keunikan yang berbeda dari event lainnya sesuai pesan yang akan disampaikan penyelenggara.

\section{b. Theme}

Suatu cara untuk membangun identitas dalam suatu kegiatan yang berbeda dan menciptakan tema narasi untuk menjelaskan mengapa seni tersebut dibuat.

\section{c. Immersion and participation.}

Pengalaman mendalam yang diberikan pada pengunjungnya menjadi sesuatu pembeda dari event lainnya yang pernah mereka kunjungi.

Dimensi tersebut dinilai sesuai karena dilihat dilihat dari festival experience dari pengunjung culture event.

\section{B. Citra Destinasi}

Setiap daerah tujuan wisata memiliki image tertentu, yaitu pandangan seseorang terhadap suatu tujuan yang mengandung keyakinan, kesan dan persepsi. Citra Destinasi merupakan keseluruhan pengetahuan, dan emosional dari seseorang individu atau kelompok terhadap suatu objek atau tempat.

Menurut Kaur et al (2015:503) Destination image adalah jumlah dari keyakinan, ide dan tayangan yang orang miliki akan suatu tempat atau destinasi. Dapat disimpukan bahwa Destination Image merupakan timbal balik dari wisatawan atas apa yang dirasakan baik melalui pengalaman maupun informasi yang diterima, dapat berupa kesan, pendapat komentar dan perasaan terhadap suatu destinasi wisata.

Kaur et. al. (2015:504) menyatakan bahwa terdapat dua dimensi citra destinasi, yaitu cognitive dan affective. Cognitive adalah berkaitan dengan atribut fisik dan faktor pengalaman seperti wisata alam, iklim, budaya, tempat wisata, kehidupan malam dan hiburan, infrastruktur, akomodasi, belanja, tingkat kebersihan, keamanan, dan biaya/harga, fasilitas dll. Atribut-atribut ini untuk mempengaruhi pembentukan dan mengubah citra destinasi. Sedangkan affective adalah Penilaian afektif kualitas lingkungan. Image afektif ditandai dengan afektif tayangan atau perasaan bahwa seorang individu memiliki tujuan tertentu.

\section{Kerangka Pemikiran}

Konsep bauran pemasaran (marketing mix) masa kini yang dikemukaakan oleh Kotler Keller (2016:48) menyebutkan bahwa terdapat 8 bauran pemasaran, yaitu product, price, place, promotion, people, processes, program dan performance. Salah satu alat dalam pemasaran yang efektif melalui promosi yang di dalamnya terdapat marketing communications mix. Lovelock dan Wirtz (2011:195) mengungkapkan bahwa terdapat enam kegiatan dalam Marketing communication mix, yaitu Personal communication, Advertising, Sales promotion, Public relations \& publicity, Instructional materials dan Corporate design. Dalam kegiatan Public relations \& publicity terdapat kegiatan special event yang di dalamnya terdapat salah satu jenis culture event.

Jennie (2015:1) mengungkapkan bahwa Culture Event merupakan suatu aktivitas budaya, yang sebelumnya disajikan dalam pola yang teratur, terus menerus, dan akan dikonfigurasikan ulang tepat untuk membuat event yang baru. Melalui festival experience terdapat tiga dimensi culture event, yaitu spectacularisation, theme, dan immersion and participation.

Dalam hal ini, peneliti mengadakan penelitian terkait program culture event pada agenda kegiatan culture event yang dilakukan Anjungan Bengkulu TMII Jakarta sebagai kegiatan dalam membangun citra destinasi wisata Provinsi Bengkulu. Dimensi yang digunakan untuk citra destinasi diadaptasi dari Kaur et al (2015:504) adalah cognitive dan affective.

Adapun dengan selalu diadakannya kegiatan ini, penulis ingin mengetahui apakah dengan kegiatan culture event ini efektif dalam membangun citra destinasi wisata Provinsi Bengkulu.

\section{Hipotesis}

Berdasarkan kerangka pemikiran yang telah dikemukakan, maka hipotesis dalam penelitian ditetapkan sebagai berikut:

Terdapat pengaruh culture event yang dilihat dari festival experience, yaitu spectacularisation, theme, dan immersion and participation terhadap citra destinasi Provinsi Bengkulu dibenak wisatawan Anjungan Bengkulu TMII Jakarta.

Berdasarkan uraian di atas maka dalam menyusun hipotesis pada penelitian ini didukung oleh beberapa premis sebagai berikut:

1. Kavaratzis dalam Dave Gelders (2012:111) mengungkapkan bahwa city's event merupakan alat komunikasi yang paling ampuh dalam menularkan citra kota yang baik.

2. Sukoco (2014:756) mengatakan bahwa event berpengaruh positif terhadap citra suatu merek. 
3. Richard dan Wilson (2004:1947) menyimpulkan bahwa culture event memiliki dampak positif dari citra kota.

4. Peta (2016:73) memiliki temuan bahwa special event sebagai suatu teknik yang inovatif untuk meningkatkan citra kota sebagai tujuan wisata.

5. Yi De Liu (2014:27) mengungkapkan bahwa culture event memiliki dampak positif dalam citra kota antara penduduk, Bisnis, media, pemirsa budaya, setidaknya sehari setelah event berlangsung.

\section{Metode Penelitian}

Penelitian ini menganalisis variabel bebas dan variabel terikat. Dalam penelitian ini yang menjadi variabel bebas yaitu, culture event $(\mathrm{X})$ yang memiliki tiga sub variabel, (X1) spectacularisation, (X2) theme, dan (X3) immersion and participation. adapun variable $\mathrm{Y}$ yang diteliti adalah citra destinasi (Y) yang memiliki indikator cognitive dan affective.

Penelitian ini dilaksanakan di daya tarik wisata budaya, yaitu Anjungan Bengkulu TMII Jakarta. Unit analisis atau responden dalam penelitian ini adalah wisatawan Anjungan Bengkulu TMII Jakarta.

Penelitian ini dilakukan pada kurun waktu kurang dari satu tahun, maka metode yang digunakan adalah cross sectional method. Menurut Husein Umar (2008:45) pendekatan cross sectional yaitu metode penelitian dengan cara mempelajari objek dalam kurun waktu tertentu/tidak berkesinambungan dalam jangka panjang. Pengumpulan informasi dari subjek penelitian hanya dilakukan satu kali dalam satu periode waktu, sehingga penelitian ini merupakan one-shot atau cross sectional (Maholtra, 2009:101). Alasan peneliti menggunakan metode ini, karena event yang diadakan di Anjungan Bengkulu berlangsung pada satu periode waktu tertentu dan tidak berkesinambungan.

Jenis penelitian yang dilakukan berdasarkan penjelasan dan bidang penelitian menggunakan penilitian deskriptif dan verifikatif. Menurut Maholtra (2009:100), penelitian deskriptif adalah jenis penilitian konklusif yang memiliki tujuan utama deskripsi dari sesuatu, biasanya karakteristik atau fungsi pasar. Penelitian deskriptif sangat berguna ketika mencari pertanyaan penelitian yang menggambarkan fenomena pasar, seperti menentukan frekuensi pembelian, mengidentifikasi hubungan atau membuat prediksi.

Tujuan penelitian deskriptif untuk menyajikan suatu profil, menjelaskan aspekaspek yang relevan dengan fenomena yang ada serta menjelaskan karakteristik berbagai variabel penelitian dalam situasi tertentu diteliti dari perspektif individual organisasi, industri dan aspek lainnya. Sehingga temuannya lebih luas, lebih dalam dan lebih terperinci. Melalui jenis penelitian deskriptif maka dapat diperoleh gambaran mengenai 1) culture event di Anjungan Bengkulu TMII Jakarta, 2) citra destinasi wisata Provinsi Bengkulu, 3) seberapa besar pengaruh culture event berbasis budaya di Anjungan Bengkulu TMII terhadap citra destinasi wisata Provinsi Bengkulu.

Sedangkan penelitian verifikatif adalah penelitian untuk menguji pengujian secara kausal, yaitu hubungan antara variabel independen dan dependen Maholtra (2009:104). Jadi penelitian verifikatif ini menguji pengaruh antara culture event di Anjungan Bengkulu TMII terhadap citra destinasi wisata Provinsi Bengkulu. Berdasarkan jenis penelitian yang digunakan yaitu penelitian jenis deskriptif dan verifikatif, maka metode yang digunakan dalam penelitian ini adalah metode survey dan explanatory survey. Menurut Jackson (2012:20) menyatakan metode survey adalah mempertanyakan individu pada sebuah topik atau beberapa topik kemudian menggambarkan tanggapan mereka. Sedangkan metode explanatory survey dilakukan untuk mengeksplorasi situasi masalah atau penelitian melalui masalah atau situasi untuk mendapatkan wawasan dan pemahaman Maholtra (2009: 98)

Populasi dalam penelitian ini adalah seluruh karakteristik yang mempengaruhi, dan anggota populasinya yakni pengunjung Anjungan Bengkulu TMII Jakarta Tahun 2016. Jumlah wisatawan yang berkunjung ke Event Pekan Seni Budaya Bengkulu di Anjungan Bengkulu TMII Jakarta yaitu sebanyak 1.391 orang.

Penulis mengambil sampel berdasarkan teknik purposive sampling. Menurut Berenson et al (2012:250) menyatakan bahwa dalam teknik purposive sampling, subjek dipilih berdasarkan karakteristiknya. Teknik ini dipilih karena populasi dan sampel yang dipilih memiliki karakteristik tertentu. Karakteristik tersebut antara lain:

1. Pengunjung Anjungan Bengkulu TMII Jakarta

2. Pengunjung culture event di Anjungan Bengkulu TMII Jakarta

3. Berusia $>15$ tahun

\section{HASIL PENELITIAN DAN PEMBAHASAN}

\section{A. Gambaran Culture Event di Anjungan} Bengkulu

Berdasarkan hasil pengolahan data, diperoleh hasil tanggapan wisatawan terhadap culture event di Anjungan Bengkulu TMII, 
dapat dilihat melalui Tabel mengenai rekapitulasi hasil tanggapan wisatawan yang merupakan hasil dari pengumpulan data yang telah dipaparkan sebelumnya.

TABel 1. Rekapitulasi Hasil TANGgapan Wisatawan TERHADAP CULTURE EVENT DI ANJUNGAN BENGKULU TMII

\begin{tabular}{llcc}
\hline No & \multicolumn{1}{c}{ Sub Variabel } & Skor Rata-Rata & $\%$ \\
\hline 1 & Spectacularisation & 437 & 36,43 \\
2 & Theme & 446 & 27,90 \\
3 & Participation and & 428 & 35,67 \\
& Immersion & & \\
\hline Total & 1311 & 100 \\
\hline
\end{tabular}

Berdasarkan Tabel di atas, menunjukan bahwa sub variabel yang memiliki nilai tertinggi adalah spectacularisation dengan nilai sebesar $36,43 \%$ sedangkan sub variabel yang memiliki penilaian terendah adalah Theme dengan persentase sebesar $27,90 \%$.

B. Gambaran Citra Destinasi Wisata Provinsi Bengkulu

Berdasarkan hasil pengolahan data, diperoleh rekapitulasi tanggapan wisatawan terhadap citra destinasi wisata Provinsi Bengkulu sebagai berikut:

TABEL 2. REKAPITULASI HASIL TANGGAPAN WISATAWAN TERHADAP CITRA DESTINASI WISATA DI ANJUNGAN BENGKULU TMII

\begin{tabular}{llcc}
\hline No & Sub Variabel & Skor Rata-Rata & $\%$ \\
\hline 1 & Cognitive & 490 & 57 \\
2 & Affective & 500 & 43 \\
\hline Total & 990 & 100 \\
\hline
\end{tabular}

Tabel di atas menunjukkan bahwa indikator yang memperoleh rata-rata skor tertinggi adalah cognitive dengan perolehan skor sebesar $57 \%$. Tingginya indikator cognitive dikarenakan citra yang dibangun dan disampaikan terhadap destinasi wisata Provinsi Bengkulu kepada pengunjung event telah dapat mempengaruhi pengetahuan yang ada di pikiran.

Tanggapan tamu individu yang terendah adalah pada affective dengan skor $43 \%$. Hal ini terjadi karena citra yang dibangun dan disampaikan terhadap destinasi wisata Provinsi Bengkulu pada pengunjung yang datang di event Anjungan Bengkulu TMII belum terlalu dapat melekat ke dalam perasaan.

\section{Pengaruh Culture Event Terhadap Citra \\ Destinasi Wisata Provinsi Bengkulu}

Persamaan regresi berganda merupakan hasil persamaan dari proses untuk menentukan persamaan prediksi yang paling akurat dari multiple/ beberapa prediktor Gravetter \& Forzano (2012:415). Sehingga dalam penelitian ini didapatkan persamaan regresi berganda untuk pengaruh culture event terhadap citra destinasi dapat dinyatakan sebagai:

$$
\begin{aligned}
& Y=a+b_{1} X_{1}+b_{2} X_{2}+b_{3} X_{3} \\
& Y=5,222+0,794 X_{1}-0,148 X_{2}+0,936 X_{3} \\
& \text { Keterangan: } \\
& Y \quad=\text { Citra Destinasi } \\
& X_{1}=\text { Spectacularisation } \\
& X_{2}=\text { Theme } \\
& X_{3}=\text { Partiipation and immersion }
\end{aligned}
$$

Hasil analisis menunjukkan nilai konstanta 5,222 artinya jika $\mathrm{X}_{1}, \mathrm{X}_{2}, \mathrm{X}_{3}$, diabaikan maka tingkat citra destinasi adalah sebesar 5,222. Koefisien $\mathrm{X}_{1}$ sebesar 0,794 berarti bahwa untuk setiap penurunan satu satuan nilai spectacularisation akan menurunkan nilai citra destinasi sebesar 0,794. Koefisien $\mathrm{X}_{2}$ sebesar 0,148 berarti bahwa untuk setiap penurunan satu satuan nilai theme akan menurunkan nilai citra destinasi sebesar 0,148. Sedangkan koefisien $\mathrm{X}_{3}$ sebesar 0,936 berarti bahwa untuk setiap kenaikan satu satuan nilai participation and immersion akan menaikan nilai citra destinasi sebesar 0,926. Sehingga Seksi Promosi dan Informasi Anjungan Bengkulu TMII harus meningkatkan participation and immersion melalui keikutsertaan pengunjung pada event yang diselenggarakan sehingga meningkatkan antusiasme pengunjung untuk meningkatkan citra destinasi wisata Anjungan Bengkulu TMII. Dimensi tersebut perlu ditingkatkan karena dimensi participation and immersion memiliki nilai kontribusi tertinggi dalam meningkatkan citra destinasi wisata Provinsi Bengkulu.

\section{KESIMPULAN}

Berdasarkan hasil penelitian yang telah dilakukan dengan menggunakan analisa deskriptif dan verifikatif serta teknik analisis regresi berganda, antara culture event di Anjungan Bengkulu TMII terhadap cita destinasi wisata Provinsi Bengkulu, maka dari penelitian tersebut dapat diambil kesimpulan sebagai berikut:

1. Secara umum tanggapan responden mengenai pelaksanaan culture event di Anjungan Bengkulu TMII yang terdiri dari 3 dimensi yaitu spectacularisation, theme dan participation and immersion berada di kategori sangat tinggi. Dimensi spectacularisation mendapatkan penilaian tertinggi. Pada spectacularisation pengunjung event merasakan kemeriahan dan keunikan yang berbeda pada event yang diselenggarakan, sehingga pesan yang disampaikan terwakili dalam keunikan event tersebut. Sedangkan penilaian terendah pada dimensi theme, dikarenakan pengunjung kurang peduli akan tema yang disajikan, dan 
lebih antusias melihat penampilan yang disajikan oleh event tersebut.

2. Tanggapan responden mengenai citra destinasi Provinsi Bengkulu yang terdiri dari cognitive dan affective. Penilaian tertinggi ada pada pemilihan cognitive, dimana citra yang dibangun dan disampaikan terhadap destinasi wisata Provinsi Bengkulu kepada pengunjung event telah dapat mempengaruhi pengetahuan yang ada di pikiran pengunjung event di Anjungan Bengkulu. Sedangkan penilaian terendah yaitu affective, dimana citra yang dibangun dan disampaikan terhadap destinasi wisata Provinsi Bengkulu pada pengunjung yang datang di event Anjungan Bengkulu TMII belum terlalu dapat melekat ke dalam perasaan.

3. Culture event yang terdiri dari spectacularisation, theme dan participation and immersion memiliki pengaruh yang signifikan terhadap citra destinasi wisata.

Berdasarkan hasil penelitian yang telah dilakukan, maka penulis memberikan rekomendasi mengenai culture event di Anjungan Bengkulu TMII terhadap citra destinasi wisata Provinsi Bengkulu, yaitu:

1. Penilaian terendah terhadap culture event di Anjungan Bengkulu TMII pada dimensi theme, dikarenakan pengunjung kurang peduli akan tema yang disajikan, dan lebih antusias melihat penampilan yang disajikan oleh event tersebut. Kesesuaian tema yang ditampilkan dengan pesan yang akan disampaikan akan citra destinasi wisata Provinsi Bengkulu dapat cepat jelas diterima dan melekat di benak pengunjung event. Selain tema yang sesuai, disarankan tema yang dipilih harus konsisten dengan apa yang akan disampaikan, sehingga pengunjung dapat lebih peduli dan mengerti akan tema yang disajikan.

2. Berdasarkan hasil penelitian dan fakta pada variabel citra destinasi wisata Provinsi Bengluku memiliki penilaian yang sangat tinggi, namun pihak penyelenggara event yaitu seksi promosi dan informasi Anjungan Bengkulu harus memperhatikan indikator affective yang masih kurang maksimal. Hal ini terjadi karena citra yang dibangun dan disampaikan terhadap destinasi wisata Provinsi Bengkulu pada pengunjung yang datang di event Anjungan Bengkulu TMII belum terlalu dapat melekat ke dalam perasaan. Disarankan penyelenggara event dapat lebih memberikan gambaran positif terhadap Provinsi Bengkulu di dalam sebuah event terutama pada bidang pariwisata.

3. Untuk meningkatkan citra destinasi wisata Provinsi Bengkulu melalui pelaksanaan culture event di Anjungan Bengkulu TMII agar lebih difokuskan pada tingkat participation and immersion, serta seksi promosi dan informasi Anjungan Bengkulu diharapkan dapat mengendalikan dan mengembangkan culture event sebagai suatu strategi pemasaran dan diharapkan selalu melibatkan pengunjung pada event-event yang diselenggarakan agar pengunjung tertarik untuk melihat, sehingga citra yang dibangun dan disampaikan dapat lebih cepat tersampaikan dan mudah diterima pengunjung event.

4. Penulis menyadari dalam penelitian ini tentunya memiliki kekurangan dan keterbatasan. Saran selanjutnya perlu dilakukan penelitian lebih lanjut mengenai variabel di luar variabel yang diteliti, misalnya advertising, public relation, sales promotion dan sebagainya. Begitu juga dengan penelitian ini yang memiliki kekurangan dan keterbatasan karena hanya dilakukan pada pengunjung culture event di Anjungan Bengkulu. Para peneliti selanjutnya dapat melakukan penelitian yang mencakup keseluruhan segmen wisatawan terhadap keputusan berkunjung dan perilaku wisatawan Provinsi Bengkulu.

\section{DAFTAR RUJUKAN}

Sumber Buku:

Ali, H. (2008). Marketing. Yogyakarta: Media Pressindo.

Arikunto, S. (2010). Prosedur Penelitian Suatu Pendekatan Prakitik. Jakarta: Reneka Cipta.

Berenson, M.L et.al. (2012). Basic Business Statistics Concept and Aplication $12^{\text {th }}$ Edition. New Jersey: Prentice Hall

Budi, T.P. (2005). SPSS 13 Terapan Riset Statistik Parametrik. Yogyakarta: Andi.

Cooper, D. R. \& Schindler, P.S. (2006). Bussines Research Methods, 9th edition. New York: McGraw-Hill.

Gelgel, I.P. (2006). Industri Pariwisata Indonesia Dalam Globalisasi Perdagangan Jasa (GATS-WTO). Bandung: Refika Aditama

Gravetter, F.J \& Forzano, L.B. (2012). Research Methods for The Behavioral Sciences. Canada: Wadsworth Cangage Learning

Keegan, W.J. (2005). Global Marketing 4th Editon International Edition. USA: Prentice Hall

Kennedy, J.E dan Soemanagara, R.D. (2006). Marketing Communications, Taktik dan Strategi. Jakarta: PT Bhuana Ilmu Populer. 
Kotler, P \& Amstrong, G. (2008). Principles of Marketing 11th Edition. New Jersey: Prentice Hall.

Kotler, P Et all., (2012). Marketing Management. 14th Edition. New Jersey: Prentice Hall, Pearson Education.

Kotler, P dan Keller, L.K. (2016). Marketing Management. 15th Global Edition. New Jersey: Prentice Hall, Pearson Education.

Lary, P. (2008). Strategic Integrated Marketing Communication Theory and practice. First edition. Typeset by Charon Tec Ltd (A Macmillan Company), India: Chennai

Lovelock, C \& Wirtz, J. (2011). Services Marketing.7th Edition. New Jersey: Prentice Hall, Pearson Education.

Malhotra, N.K. (2009). Riset Pemasaran Edisi keempat Jilid 1. Jakarta: PT Indeks

Mathis, R.L \& Jackson, J.H. (2012). Manajemen Sumber Daya Manusia, Edisi Pertama. Jakarta: Salemba Empat

Noor, A. (2013). Manajamen Event. Edisi Revisi. Bandung: Alfabeta.

Noor, J. (2014). Metodologi Penelitian. Jakarta: Kencana.

Pike, S.D. (2008). Destination Marketing: An Integrated Marketing Communication Approach. Butterworth-Heinemann, Burlington, MA.

Pitana, I.G \& Gayatri, P.G. (2005). Sosiologi Pariwisata. Yogyakarta: Andi.

Rangkuti, F. (2011). Riset Pemasaran. Cetakan ke 10. Jakarta: PT. Gramedia.

Riduwan. (2010). Dasar-Dasar Statistika. Bandung: Alfabeta.

Sekaran, U \& Roger, B. (2013). Research Methods for Business. India: Thomson Digital.

Silalahi, U. (2012). Metode Penelitian Sosial. Bandung: PT. Refika Aditama.

Stangor, C. (2011). Research Method for Behavioral Science. Wadsworth: Cengage Learning.

Suwantoro, G. (2004). Dasar-Dasar Pariwisata. Yogyakarta: Andi.

Tabachnick, B.G. dan Fidell, L.S. (2013). Using Multivariate Stastistics. Boston: Pearson Education.

Yoeti, O.A. (2013). Pemasaran Pariwisata. Bandung: Angkasa.

Sumber Jurnal:

Fitriani, M \& Andari, R. (2013). Meningkatkan Keputusan Berkunjung Melalui Special Event Di Museum Konperensi Asia Afrika. Tourism and Hospitality Essentials Journal, 3(2), 619-631
Gelders, D. (2013). City events: Short and Serial Reproduction Effects on The City's Image?. An International Journal, 18(1), $110-118$

Jennie, J. (2015). Festivalisation of Cultural Production. 6th Annual Research Session, 244-255.

Kaur, A, et al. (2015). Destination Image of Indian Tourism Destinations. Asia Pacific Journal of Marketing and Logistics, 28(3), 499-524.

Liu, Y.D. (2014). The Impact of Cultural Event on City Image: An Evaluation of The 2008 European Capital of Culture, Liverpool. Int. J. Leisure and Tourism Marketing, 4(1)

Rajesh, R. (2013). Impact of Tourist Perceptions, Destination Image and Tourist Satisfaction on Destination Loyalty: A Conceptual Model. Revista de Turismo y Patrimonio Cultural. 11(3) Special Issue, 67-78.

Richards, G \& Wilson, J. (2004). The Impact of Cultural Events on City Image: Rotterdam, Cultural Capital of Europe 2001. Journal of Urban Studies, 41(10), 1931-195.

Sneat, J.Z dan Finney, R.Z. (2008). An IMC Approach to Event Marketing the Effect of Sponshorship and Experience On Customer Attitude. Journal of Advertising Research.

Sukoco, M.H. (2014). Pengaruh Pemasaran Event Terhadap Citra Merek Minuman Isotonik Mizonedi Surabaya. Jurnal Ilmu Manajemen, 2(3)

Sumber Skripsi, Tesis dan Disertasi:

Bambang, Y.D. (2016). Pengaruh Destination Image Jepang Terhadap Keputusan Berkunjung Wisatawan Indonesia. (Skripsi). Fakultas Pendidikan Ilmu Pengetahuan Sosial. Universitas Pendidikan Indonesia.

Jago, K.L. (1997). Special Events and Tourism Behaviour: A Conceptualisation and An Empirical Analysis From A Values Perspective. (Tesis). Department of Hospitality, Tourism and Marketing Faculty of Business, Victoria University.

Peta, M. (2016). Special Events as an Innovative Technique for Improving Zimbabwe's Image as A Tourist Destination. (Skripsi). Department of Hospitality and Tourism Chinhoyi University of Technology.

Soonleitner, K. (2011). Destinations Image and its effects on marketing and branding a 
tourist destination: A case study about the Austrian National Tourist Office-with a focuso the market Sweden. (Disertasi). School of Business Studies Sodertorn University.

Admin. (2017). Gaungkan Visit Wonderful Bengkulu 2020. [Online]. Diakses dari: http://harianrakyatbengkulu.com/ver3/20 17/03/27/gaungkan-visit-2020wonderful-bengkulu/ Admin. (2017). Pembinaan Kelompok Sadar Wisata Se Provinsi Bengkulu. [Online]. Diakses dari: http://harianrakyatbengkulu.com/ver3/20 17/04/10/114493/ 